\title{
IDENTIFICANDO OS DETERMINANTES DA INADIMPLÊNCIA CONTRATUAL NO PROGRAMA AGROAMIGO CRESCER ${ }^{1}$
}

Emanoel Márcio Nunes ${ }^{2}$

Fábio Lúcio Rodrigues ${ }^{3}$ Camila Escobar ${ }^{4}$

Resumo: O objetivo do trabalho é identificar determinantes da inadimplência dos tomadores de financiamento do Programa Agroamigo Crescer Pecuária, no período de 2005 a 2017, atribuindo probabilidades a cada fator relacionado. Como metodologia, dentre as diversas variações dos modelos de atribuição de probabilidades, este trabalho utiliza o modelo LOGIT de resposta binária. Os resultados obtidos para o modelo de inadimplência estimado apontam para o sentido correto das relações empíricas percebidas. Temos que o aumento do valor do contrato aumenta a chance do tomador se tornar inadimplente e que o aumento do prazo reduzirá essa possibilidade. Enquanto que a finalidade direcionada a investimentos, essa a maior proporção dos contratos, aumentara o risco da inadimplência.

Palavras-chave: Inadimplência. Agricultura familiar. Microcrédito. Pecuária.

\section{IDENTIFYING THE DETERMINANTS OF CONTRACTUAL INADIMPLENCE IN THE “AGROAMIGO CRESCER” PROGRAM}

Abstract: The goal of this work is to identify determinants of default by money borrowers of the Agroamigo Crescer Pecuária Program, from 2005 to 2017, assigning probabilities to each related factor. As a methodology, among a set of variations of the probability attribution models, this work uses the LOGIT model of binary response. The results obtained for the estimated default model point to the correct direction of the perceived empirical relationships. We have that increasing the contract value increases the chance of the borrower becoming in default and that increasing the term will reduce this possibility. While the purpose of investments, this the largest proportion of contracts, will increase the risk of default.

Keywords: Inadimplence. Family farming. Microcredit. Livestock.

\section{IDENTIFICACIÓN DE LOS DETERMINANTES DE INCUMPLIMIENTO CONTRACTUAL EN EL PROGRAMA "AGROAMIGO CRESCER"}

Resumen: El objetivo del trabajo es identificar los determinantes de incumplimiento por parte de los prestatarios del Programa Agroamigo Crescer Pecuária, de 2005 a 2017, asignando probabilidades a cada factor relacionado. Como metodología, entre las diversas variaciones de los modelos de atribución de probabilidad, este trabajo utiliza el modelo LOGIT de respuesta binaria. Los resultados obtenidos para el

\footnotetext{
${ }^{1}$ Este trabalho faz parte de um conjunto de pesquisas desenvolvidas no âmbito da agricultura familiar e do desenvolvimento regional, e contou com o auxílio do CNPq através do edital Chamada Encomendas COSAE MDA 2013 (APQ).

2 Universidade do Estado do Rio Grande do Norte (UERN), Departamento de Economia, Mossoró/RN, Brasil, emanoelnunes@uern.br, https://orcid.org/0000-0002-9045-887X

${ }_{3}^{3}$ Universidade do Estado do Rio Grande do Norte (UERN), Departamento de Economia, Mossoró/RN, Brasil, fabiolucio@uern.br, https://orcid.org/0000-0001-5809-4044

${ }^{4}$ Universidade do Estado do Rio Grande do Norte (UERN), Departamento de Economia, Mossoró/RN, Brasil, camila.escoba@gmail.com, https://orcid.org/0000-0002-2379-3731
} 
modelo predeterminado estimado apuntan a la dirección correcta de las relaciones empíricas percibidas. Tenemos que aumentar el valor del contrato aumenta las posibilidades de que el prestatario se convierta en incumplimiento y que aumentar el plazo reducirá esta posibilidad. Si bien el propósito de las inversiones, esta es la mayor proporción de contratos, aumentará el riesgo de incumplimiento.

Palabras-clave: Incumplimiento. Agricultura familiar. Microcrédito. Ganado.

\section{Introdução}

Numa trajetória caracterizada por ações de desenvolvimento regional, o Banco do Nordeste do Brasil (BNB) vem atuando desde o ano de 1952, e tem como área de abrangência geográfica os nove estados da região Nordeste e o norte dos estados de Minas Gerais e do Espírito Santo, área definida como de abrangência da Superintendência de Desenvolvimento do Nordeste (SUDENE). As suas ações têm sido no sentido de fazer com que as forças necessárias para o dinamismo dessas regiões sejam capazes de reduzir desigualdades e erradicar a pobreza extrema, especialmente do interior do Nordeste brasileiro. Para isso, o BNB tem, na sua existência, buscado apoiar atividades potenciais para a geração de riquezas, com o interesse de elevar os níveis de renda, principalmente em relação à região CentroSul do Brasil. Dentre as atividades exercidas pelo BNB, destacam-se os maiores e mais importantes programas de microfinanças do país: o Crediamigo e o Agroamigo.

O Programa de Microcrédito Produtivo Orientado (Crediamigo) foi implantado em 1998, possibilitando há vários empreendedores de áreas urbanas expandirem seus pequenos negócios. A partir de 2005, o BNB passou a atuar nas áreas rurais e atender agricultores familiares através do Programa de Microcrédito Rural Orientado e Acompanhado (Agroamigo), incentivando a educação financeira e ampliação de suas atividades agrícolas e produtivas. Ao todo são 11 estados atendidos pelo Agroamigo, os 9 (nove) Estados do Nordeste e norte de Minas Gerais e do Espírito Santo (BNB, 2017).

Dentre essas regiões de atendimento, aproximadamente $69 \%$ dos clientes atendidos pelo Agroamigo estão situados no semiárido, onde as famílias possuem renda inferior a 10.000 (dez mil) reais por ano, indicando assim que o microfinanciamento busca atender as famílias mais carentes que desenvolvem atividades econômicas ainda muitas vezes precárias. Visto que um fator que desencadeia essa perspectiva é o baixo nível de escolaridade dos clientes do meio rural, apenas $8 \%$ possuem o ensino médio completo, onde aproximadamente $53 \%$ possuem o ensino fundamental incompleto (BNB, 2017). 
Além disso, o público feminino que adere ao microcrédito rural vem aumentando consideravelmente ao longo dos anos, sendo que $53 \%$ dos clientes são do gênero masculino, e 47\% são do gênero feminino, isso porque as atividades não agrícolas vêm ganhando espaço no meio rural no âmbito da agricultura familiar, onde as principais atividades são a pecuária, agricultura, serviços e extrativismo.

O programa busca diversificar e tem oferecido serviços, a exemplo de cartão de crédito e seguro de vida, para facilitar as transações financeiras. Possui também o Agroamigo Mais para agricultores familiares com renda bruta entre $R \$ 20.000$ a $R \$$ 360.000 por ano e criou, em 2017, o Agroamigo Sol com o intuito de incentivar o investimento a energia renovável para os agricultores utilizarem e assim reduzir os custos e não prejudicar o meio ambiente. E outro é o Agroamigo Crescer, que busca atender às famílias do Pronaf (Programa Nacional de Fortalecimento da Agricultura Familiar) com renda bruta de até $\mathrm{R} \$ 20.000$ por ano e, além disso, ainda integra junto com o Governo Federal programas como Proagro Mais, Merenda Escolar, Assistência Técnica, Programa de Garantia de Preços para Agricultura FamiliarPGPAF e o Bolsa Família. Oferece, ainda, atendimento nas comunidades próprias do cliente, bônus para tomadores que pagam em dia, juros mais baixos que a média dos Bancos e agentes de microcrédito que acompanham e orientam o cliente em todas as fases da negociação (BNB, 2017).

Comparado com o ambiente de crise e de instabilidade da economia brasileira, e o aumento do número de inadimplentes nesses últimos anos, o índice de inadimplência registrado pelo Banco entre 2013 a 2017 é de apenas 3,2 \% em média, tendo em vista o número de 1.214.344 de cliente ativos registrados até o ano de 2017, no qual o valor médio dos financiamentos chegou a 4.471,00 neste mesmo ano, com uma média de operações contratadas de 43.220 mil por mês (BNB, 2017).

De acordo com Aquino e Bastos (2015), em sua primeira década de existência, o Programa de Microcrédito Rural - Agroamigo alcançou resultados importantes em sua operacionalização. No período de 2005 a 2017, o programa realizou mais de 2,4 milhões de operações de crédito e aplicou um montante de recursos superior a 5,6 bilhões, apresentando uma taxa de adimplência superior a 95\%. No entanto, os autores constataram que o Agroamigo apresentou nesse período de doze anos um baixo grau de cobertura e efeitos socioeconômicos limitados. Segundo Nunes et al (2015), também cabe destaque para os níveis elevados de investimentos, devido a ainda precária e carente infraestrutura da região Nordeste, impactando na limitação da renda dos agricultores familiares. Nesse sentido, uma das principais finalidades 
do Agroamigo é manter baixo o nível de inadimplência dos agricultores familiares tomadores de recurso do programa. Diante do exposto, o presente estudo buscou responder o seguinte questionamento: qual o nível de inadimplência do Programa Agroamigo Crescer Pecuária nos seus doze anos na região Nordeste e norte de Minas Gerais e do Espírito Santo, ou seja, de 2005 a 2017; e quais os determinantes da inadimplência dos agricultores familiares beneficiários desta linha do Programa?

A hipótese é a de que os recursos do Agroamigo para a região Nordeste e norte dos estados de Minas Gerais e do Espírito Santo, têm sido predominantemente direcionados para cadeias produtivas tradicionais, especialmente para a pecuária, necessitando ampliar o acesso desta modalidade de Microcrédito para cadeias produtivas novas. Por outro lado, a inadimplência se manteve relativamente baixa na análise dos doze anos do Agroamigo, apesar das dificuldades de operacionalização do Microcrédito, assim como de outros serviços financeiros por parte dos agricultores familiares mais pobres. Essas dificuldades, quando não consideradas, tendem a limitar a possibilidade de um processo de estruturação produtiva, de organização coletiva, do acesso a mercados e da diversificação da agricultura familiar.

Por esta razão, o objetivo deste trabalho é identificar os determinantes da inadimplência dos agricultores familiares a região Nordeste e norte dos estados de Minas Gerais e do Espírito Santo, tomadores de financiamento do Programa Agroamigo Crescer Pecuária, atribuindo probabilidades a cada fator relacionado.

\section{Inadimplência, microcrédito e agricultura familiar}

Conforme apontam Famá e Securato (1997) e Santos (2006), um indivíduo pode ser considerado inadimplente quando se encontra em situação de insuficiência financeira para honrar compromissos, a exemplo de não conseguir realizar o pagamento de suas dívidas até a data prevista em contrato, seja este contrato tácito ou formal. São vários os determinantes da inadimplência, seja de indivíduos, de famílias ou de empresas que muitas vezes recorrem a empréstimos para cumprir a um desejo imediato ou atender uma demanda mais urgente. A inadimplência geralmente está relacionada com realidades de instabilidade que quase sempre se traduzem em contextos submetidos a uma retração da economia que gera crise econômica. Geralmente essas realidades, ou contextos, ocorrem e são recorrentes logo depois de terem passado por uma expansão da economia com níveis mais favoráveis da produção, com ampliação do emprego e da renda, e que gozaram no 
período de um aumento do volume de crédito com maior oferta de recursos financeiros para empréstimos.

Muitas vezes, quando a economia se retrai e a crise econômica se instala, a produção de riqueza arrefece e a instabilidade e a vulnerabilidade crescem fazendo com que os níveis de desemprego afirmem uma tendência para aumentar e os níveis de renda a diminuir. Nesta realidade, muitos dos tomadores dos empréstimos de um período econômico anterior e mais favorável são impactados, perdem totalmente ou simplesmente reduzem suas rendas, se tornando incapacitados de honrar de forma pontual as amortizações dos empréstimos ou de outros compromissos firmados. Neste sentido, o endividamento das pessoas e das famílias se torna cada vez maior e as levam a uma redução ou anulação das suas capacidades de compra atribuindo-se, portanto, a uma maior possibilidade de inadimplência quando o valor da renda se tornar menor e insuficiente, especialmente para amortizar as prestações do empréstimo. De acordo com Oliveira e Coronato (2016), as famílias que ficam inadimplentes são levadas muitas vezes à situação de negativadas e correm o risco, inclusive, de passarem por constrangimentos devido à perda da reputação, da credibilidade por serem boas pagadoras e da incapacidade de se manter em condições de comprar e de acessar o crédito.

Existem dois tipos mais comuns de endividamentos: 1) o endividamento passivo; e 2) o endividamento ativo. Faria (2006) ressalta que o endividamento passivo acontece quando há um aumento de dívidas devido à alguma situação inesperada e que submete o indivíduo ou a família, ou seja, uma circunstância imprevista e de caráter externo, podendo ser causada por crise econômica, doença, intempéries, morte, acidente, desemprego ou separação. Já o endividamento ativo se caracteriza pela ação do próprio indivíduo ou família, de caráter interno, onde são construídas dívidas sem o menor planejamento, sendo a maioria equivocada, e muitas vezes resultantes de uma desastrosa gestão financeira. São indivíduos ou famílias que estão constantemente endividados, independentemente de sua renda financeira ou familiar. Trindade et al (2012) relata que o problema das pessoas surge, muitas vezes, na falta de educação financeira, tendo como base a deficiência ou mesmo a total ausência de planejamento. Nos dias atuais, para que haja controle financeiro é preciso um bom orçamento seja feito, contudo, é necessário que possua uma boa estratégia para desviar dos momentos difíceis evitando o consumismo desenfreado da população. $O$ endividamento exagerado é um reflexo da sociedade 
de consumo e caracteriza-se como um problema de ordem social e não individual, que afeta consumidores e fornecedores (TRINDADE et. al., 2012).

Para Douat (1994), as pessoas têm gastos que muitas vezes ultrapassam os limites dos seus orçamentos e vão além do que as suas rendas permitem. Ao se deparar com este tipo de situação, o endividado recorre a bancos, financeiras ou vai para o mercado informal controlado pelos agiotas. A princípio isso pode parecer uma solução, mas também é um risco de piorar a situação. Dessa forma o endividado pode ficar seriamente negativado e com o nome cadastrado no Serviço de Proteção ao Crédito (SPC) e na Serasa ${ }^{5}$. A crise económica decorre em algum momento de dificuldade do consumidor de cumprir com uma obrigação, com isso lhe é ofertado propostas creditícias para a satisfação destas dívidas, criando assim, um amontoado de obrigações que são acumuladas e crescentes ao longo do tempo.

Trazendo para o meio rural, conforme constata Nunes et al (2018), não se apresenta muito comum na maioria das pesquisas e estudos sobre a dinâmica da economia rural a preocupação com a vida financeira de quem pratica atividades rurais, especialmente no âmbito da agricultura familiar. No entanto, o segmento da agricultura familiar tem se afirmado com sua importância para a dinâmica geral da economia, o que tem despertado a necessidade de políticas que possibilitem o acesso dos agricultores familiares e de suas organizações coletivas aos mais variados serviços financeiros. Para esse alcance, segundo Nunes et al (2018), se faz indispensável entender as principais estratégias que os agricultores adotam para se inserirem economicamente e ganhar o seu dinheiro, e de que maneira eles desenvolvem combinações para utilizar o mais eficientemente os seus poucos recursos. No entanto, apesar de possuírem pouco dinheiro, os agricultores familiares conseguem poupar, improvisam garantias e meios de seguro contra imprevistos e contraem empréstimos. O que mais caracteriza a vida financeira dos agricultores e de suas organizações coletivas é sua própria condição precária que os obriga a agirem no sentido de garantir sua sobrevivência.

Cabe ressaltar que a agricultura familiar tem cada vez mais se afirmado como segmento dinamizador da economia do interior e gerador de desenvolvimento no meio rural, e contribuído no processo de inclusão econômica e de redução das desigualdades. E o Agroamigo tem se mostrado importante mecanismo de política

\footnotetext{
${ }^{5}$ Fundada em 1968, a Serasa tem sua sede na cidade de São Paulo (SP), e é uma empresa privada brasileira com a responsabilidade de reunir dados e demais informações, fazer análises e pesquisar sobre a situação de pessoas físicas e jurídicas que possuem dívidas financeiras, servindo de base para muitas decisões de crédito e de negócios.
} 
de microfinanças na região Nordeste e no norte de Minas Gerais e do Espírito Santo, no sentido de oferecer serviços financeiros considerando as necessidades dos agricultores familiares e de suas organizações coletivas. Todavia, há problemas quanto aos níveis de investimento, concentrado predominantemente na cadeia produtiva da pecuária, atendendo pouco às outras cadeias produtivas e não possibilitando uma maior diversificação da economia rural (NUNES ET AL, 2015).

Apesar dessa concentração na cadeia da pecuária, conforme Nunes et al (2014), o AGROAMIGO tem tentado diversificar a agricultura familiar com atividades agrícolas e não agrícolas, visando dinamizar, "por meio de cadeias produtivas capazes de agregar valor e gerar ocupação e oportunidades dignas no meio rural". Conforme mostra a Tabela 1, dos 26.966 questionários, aproximadamente 90\% dizem respeito ao Programa Agroamigo Crescer Pecuária. Por outro lado, os investimentos são em quase sua totalidade destinada a esta única cadeia produtiva, mostrando uma agricultura familiar inserida em uma economia rural precária e com reduzida diversificação econômica. A ausência e deficiência de infraestrutura de produção econômica, especialmente na região Nordeste do Brasil, e a atividade econômica baseada na criação de gado limita a economia reduzindo à esta cadeia produtiva tradicional (NUNES ET AL, 2015).

O debate acerca do desenvolvimento rural sugere que os formuladores de políticas visem à diversificação econômica, e cabe ao Estado intervir nas ações de investimento no segmento da agricultura familiar, uma vez que num ambiente de economia frágil não é possível alcançar um processo autônomo e espontâneo de desenvolvimento, seja no meio rural ou não (NUNES ET AL, 2015).

Segundo Castillo (2008), as políticas de microcrédito têm se convertido em uma das estratégias de ação contra a pobreza e redução das desigualdades com mais destaque e reconhecimento por parte dos organismos internacionais. Castillo (2008) ressalta que o Brasil tem se destacado no cenário latino-americano por possuir dois importantes programas de microcrédito, sediados na Região Nordeste: o Crediamigo, destinado ao atendimento da população urbana; e o Agroamigo voltado ao atendimento de demandas financeiras dos agricultores familiares do semiárido nordestino e de suas organizações coletivas. 
Tabela 1 - Atividades financiadas pelo AGROAMIGO nos estados do Nordeste de 2005 a 2017 (em \%)

\begin{tabular}{|c|c|c|c|c|c|c|c|c|c|}
\hline \multirow{2}{*}{$\begin{array}{l}\text { Cadeias } \\
\text { Produtivas }\end{array}$} & \multicolumn{9}{|c|}{ Unidade da Federação } \\
\hline & BA & CE & MA & PB & PE & PI & $\mathbf{R N}$ & SE & $\mathbf{A L}$ \\
\hline Bovinocultura & 55,46 & 37,39 & 48,96 & 56,84 & 60,96 & 18,21 & 65,03 & 53,93 & 72,71 \\
\hline Suinocultura & 10,45 & 9,73 & 22,09 & 5,87 & 2,97 & 18,66 & 3,53 & 10,90 & 6,20 \\
\hline Ovinocultura & 8,76 & 12,51 & 0,36 & 4,55 & 14,17 & 19,16 & 11,43 & 10,18 & 4,41 \\
\hline Avicultura & 7,61 & 10,47 & 10,07 & 8,40 & 2,09 & 12,76 & 4,45 & 11,32 & 0,77 \\
\hline Caprinocultura & 3,31 & 4,96 & 3,13 & 3,47 & 10,25 & 20,09 & 3,75 & 0,28 & 0,47 \\
\hline Banana & 2,76 & 0,36 & 0,05 & 0,12 & 1,06 & 0,01 & 0,11 & 0,01 & 1,53 \\
\hline Serv. Aux (AES)* & 2,57 & 5,37 & 1,84 & 3,31 & 2,19 & 3,79 & 3,32 & 5,22 & 5,17 \\
\hline Mandioca & 1,84 & 0,40 & 1,39 & 0,07 & 0,37 & 0,32 & 0,55 & 0,27 & 0,84 \\
\hline Pesca & 1,34 & 1,32 & 6,47 & 0,89 & 1,06 & 2,05 & 2,05 & 1,53 & 3,12 \\
\hline Café & 1,08 & 0,01 & 0,00 & 0,00 & 0,00 & 0,00 & 0,00 & 0,00 & 0,00 \\
\hline Maracujá & 0,96 & 1,17 & 0,01 & 0,12 & 0,86 & 0,00 & 0,81 & 0,52 & 1,45 \\
\hline Piscicultura & 0,87 & 1,33 & 1,60 & 1,15 & 0,44 & 1,02 & 1,66 & 0,63 & 0,29 \\
\hline Artesanato & 0,86 & 7,47 & 1,34 & 13,85 & 1,08 & 1,51 & 1,35 & 3,31 & 1,20 \\
\hline Apicultura & 0,30 & 0,90 & 0,15 & 0,38 & 0,23 & 1,46 & 0,71 & 0,16 & 0,06 \\
\hline Alface & 0,19 & 0,17 & 0,51 & 0,07 & 0,06 & 0,10 & 0,08 & 0,02 & 0,10 \\
\hline Cana-de-Açúcar & 0,14 & 1,28 & 0,02 & 0,04 & 0,81 & 0,33 & 0,01 & 0,00 & 0,04 \\
\hline Laranja & 0,11 & 0,01 & 0,00 & 0,08 & 0,01 & 0,00 & 0,00 & 0,15 & 0,21 \\
\hline Feijão e Milho & 0,07 & 0,57 & 0,01 & 0,12 & 0,23 & 0,05 & 0,24 & 0,01 & 0,37 \\
\hline Equinocultura & 0,02 & 0,57 & 0,05 & 0,03 & 0,12 & 0,05 & 0,03 & 0,72 & 0,27 \\
\hline Caju & 0,00 & 1,14 & 0,00 & 0,01 & 0,00 & 0,04 & 0,18 & 0,00 & 0,03 \\
\hline Diversos & 1,32 & 2,86 & 1,93 & 0,63 & 1,03 & 0,40 & 0,69 & 0,84 & 0,74 \\
\hline Total & 100 & 100 & 100 & 100 & 100 & 100 & 100 & 100 & 100 \\
\hline
\end{tabular}

Fonte: Elaboração dos autores, com informações da base de dados do Agroamigo do BNB, 2017.

Segundo Aquino e Bastos (2015), além de ofertar recursos de forma orientada e acompanhada visando manter o nível de inadimplência baixo, o Agroamigo visa estruturar unidades produtivas familiares; diversificar as fontes de renda das famílias rurais, através do incentivo às atividades não agrícolas. Além disso, conforme Nunes et al (2018), almeja promover a integração do microcrédito com outras ações do Governo Federal, a exemplo do Programa Nacional de Alimentação Escolar (PNAE), serviços de Assistência Técnica e Extensão Rural (ATER), dentre outras.

Quanto ao Microcrédito, Gulli (1998) define como sendo serviços financeiros de pequena escala, que envolvam valores baixos. Por sua vez, Schreiner (2001), apud Neri e Medrado (2010), define o microcrédito não pelo valor emprestado, e sim pelo público alvo, isto é, como crédito concedido a pessoas ou famílias de baixa renda. O Banco Interamericano de Desenvolvimento (BID), define microcrédito como um pequeno crédito ofertado em larga escala por entidade financeira a pessoas físicas ou jurídicas, que tenham como principal fonte de renda as vendas oriundas da realização de atividades empresariais de produção e serviços (BID, 2008).

De acordo com Monzoni Neto (2006), no Brasil estabeleceu-se a diferenciação entre: 
a) Microcrédito: que é definido como o serviço de crédito para a população de baixa renda;

b) Microcrédito Produtivo: que é o serviço de crédito de pequeno valor destinado às atividades produtivas, e;

c) Microcrédito Produtivo Orientado: que é o serviço de crédito destinado às atividades produtivas, mas que tem por base, o relacionamento personalizado entre a instituição financeira que oferta o microcrédito e o empreendedor através da figura do agente de créditos.

A diferença entre o microcrédito produtivo e o microcrédito produtivo orientado, consiste na metodologia de concessão dos recursos financeiros, uma vez que o microcrédito produtivo orientado requer um relacionamento bem mais direto com os empreendedores, que é de responsabilidade do agente de crédito - profissional especialmente capacitado para realizar a análise de empréstimos e orientação ao empreendedor (SILVA, 2007, apud MACIEL ET AL, 2009).

Neri e Medrado (2010), afirmam que a principal vantagem do microcrédito, em seu aspecto de política social, é que ele gera incentivos para que os clientes se envolvam em atividades produtivas e tenham condições de honrar seus compromissos financeiros pagando as suas dívidas, o que possibilita aos tomadores de dinheiro a capacidade de aumentar as suas rendas. Isto devido à essa modalidade de crédito ágil, oportuna e compatível com as necessidades dos clientes, tornando-se um instrumento capaz de proporcionar uma densidade econômica e um tecido social no âmbito mais local e regional, através das oportunidades de crescimento econômico, ocupação e renda. No entanto, se faz necessário a compreensão da condição social e econômica de uma dada região, aqui a Nordeste do Brasil, para perceber os diversos agentes determinantes da construção do tecido social e da densidade econômica.

O Programa de Microcrédito Rural (Agroamigo) iniciou suas atividades em 2005, com recursos oriundos do Fundo Constitucional de Financiamento do Nordeste (FNE). O objetivo geral do Agroamigo é expandir o atendimento aos agricultores familiares, e inicialmente buscava atender os beneficiários do Programa Nacional de Fortalecimento da Agricultura Familiar (Pronaf - Grupo B). O Agroamigo pode ser classificado como microcrédito produtivo orientado, e sua metodologia de crédito tem por base a adotada pelo programa Crediamigo, com as 
devidas adaptações para o setor rural e obedecendo a seguinte sistemática (MACIEL ET AL, 2009):

- Os assessores de microcrédito rural realizam as atividades de: concessão de crédito; elaboração de cadastro de clientes; elaboração de propostas; plano de negócio; acompanhamento e renovação de crédito;

- As agências do BNB são responsáveis pelas atividades decorrentes da concessão de crédito: deferimento; cadastramento; contabilização e outros serviços.

O Programa Nacional de Fortalecimento da Agricultura Familiar (PRONAF), criado em 1996, surge como mecanismo de política de crédito rural para atender a parcela mais frágil economicamente, a dos agricultores familiares, principalmente aqueles que produzem para o autoconsumo, uma vez que sempre tiveram mais dificuldade de conseguir crédito pelos meios convencionais. Neste meio surge o Agroamigo, um mecanismo de política de microcrédito rural que atua no sentido de atender o seu público alvo por meio da concessão de crédito nas modalidades custeio e investimento, originalmente para os agricultores familiares denominados de grupo B do Pronaf. Devido ao sucesso do programa, a sua área de atuação se estendeu ao ponto de se tornar o maior programa de microcrédito rural da América do Sul (AQUINO; BASTOS, 2015).

Há diferentes linhas de concessão de crédito para o Programa, e o Agroamigo Crescer Pecuária torna-se relevante na análise deste trabalho por destacar problemas que fizeram crescer o nível de inadimplência do setor B do Pronaf, categoria mais vulnerável do programa e público alvo do programa Agroamigo Crescer. Desde sua criação, o Pronaf B foi ampliado significativamente e passou por diversas mudanças visando o aprimoramento contínuo do Pronaf. Separou os agricultores familiares por categorias (A, B, C e D), uma vez que esta categoria se caracteriza pela diferenciação econômica e social, pois, como apontam Nunes et al (2020), é heterogênea no que diz respeito às suas condições socioeconômicas e capacidade de acesso aos mercados. Grupos que passaram a ser separados pelo nível de renda anual dos produtores, exceto o grupo $A$, que englobava as famílias do Programa de Crédito Especial para a Reforma Agrária (PROCERA). A ideia era permitir uma maior regulação administrativa do programa, levando a concessão de credito e forma de pagamento mais justa conforme a situação socioeconômica dos agricultores familiares (MAIA; PINTO, 2015). 
Para trabalhar os aspectos ligados ao alcance do Pronaf, Maia e Pinto (2015) ressaltam a forma com que o programa pretendia se estender dada a limitação do número de agências bancárias que possuía o BNB, ou reduzida bancarização, onde foram utilizados escritórios de empresas de Assistência Técnica e Extensão Rural (ATER). Os agricultores familiares enquadrados no grupo B do Pronaf se dirigiam aos escritórios de ATER e eram intermediados por um funcionário que lhe explicava o modo de concessão de crédito. Eram mostradas as suas vantagens em comparação com as linhas de crédito de outras agencias bancarias que dificilmente teriam condições de pagamento devido as exorbitantes taxas de juros, e também sobre as formas de pagamento dos empréstimos de investimento e custeio. Isto fez com que o programa chegasse a localidades onde não existiam agencias do BNB.

Segundo Neri e Medrado (2010), havia mesmo um processo de reduzida bancarização, onde $90,56 \%$ dos agricultores familiares não tinham contas bancárias, alguns apenas com poupança. Após o surgimento e desenvolvimento do microcrédito o número de famílias rurais que possuíam acesso ao sistema bancário aumentou significativamente. Todavia, não se notou elevação da bancarização com aumento de agencias bancarias do BNB, uma vez que havia intermediadores entre o agricultor e o agente financeiro, intermediação que acontecia nos escritórios de ATER pelos assessores de microcrédito rural.

A despeito da diminuição de inadimplentes no ano de 2008 , segundo dados do Relatório de microfinanças do BNB (2013) vale destacar a figura importante do assessor de microcrédito rural, intermediador entre o agricultor familiar e o banco, que através de entrevistas ajudou a difundir a finalidade correta do financiamento bem como as formas de pagamentos mais flexíveis para o Grupo B do PRONAF. Essas entrevistas eram uma forma de dar destaque aos aspectos positivos do programa para o pequeno produtor rural e o bônus trazido com a adimplência. Além disso, a carteira do assessor é avaliada com os contratos de financiamentos fechados com os agricultores e o nível de adimplência que sua carteira possui (MAIA; PINTO, 2015).

Maia e Pinto (2015) destacam a importância dos microempreendedores rurais, os agricultores familiares, na diminuição dos níveis da pobreza, sendo estes os potenciais clientes do Agroamigo. Traçaram o perfil desse público conforme suas condições socioeconômicas no que diz respeito ao acesso a água (30,21\%), energia elétrica (96\%) e acesso a mercados, especialmente a comercialização em mercados 
locais e regionais (95\%). A comercialização local conta em quase sua totalidade pela atividade pecuarista e tem uma logística de transporte precária.

A inadimplência do grupo $B$ do Pronaf continuou a persistir e foi resultado de diferentes motivos a se mencionar. Como já ressaltado, este grupo faz parte de uma parcela economicamente vulnerável, sabe-se das instabilidades que são expostas aos indivíduos e famílias que atuam na agricultura familiar. Diferente de outras atividades de produção, ela está exposta a externalidades mais do que outras, pois, depende, sobretudo, de condições climáticas para produzir e de preços atraentes que vem a afetar oferta e demanda, havendo instabilidade na renda dos agricultores familiares e suas organizações coletivas. A falta de conhecimento sobre os objetivos reais do programa fez os agricultores familiares se desviarem da finalidade do financiamento, para atividades não agrícolas, usando o dinheiro para pagamentos de dívidas, sustentação de suas famílias etc. A falta de orientação para a finalidade e a ausência de penalidade para o não pagamento, também fez crescer a cultura de inadimplência, pressionando as contas da União, o que fez suspender este tipo de financiamento em muitos municípios (AQUINO; BASTOS, 2015).

Aquino e Bastos (2015) sinalizam pontos de atenção que devem ser aprimorados com a experiência do Pronaf $B$. A pecuária é a atividade dominante em que os financiamentos do Agroamigo atingem diretamente, dão destaque para a forma isolada que o microcrédito atua, no sentindo de não dinamizar a economia no meio rural, devendo dar maior alcance para atividades não agrícolas. Buscando atingir este objetivo entre 2005 e 2013, o Agroamigo deu início ao financiamento de outros setores não pecuários no Nordeste, como o setor de comercio e serviços. Aquino e Bastos (2015) corroboram dando destaque para as cadeias produtivas que o Agroamigo atinge diretamente, são elas a: bovinocultura, suinocultura, ovinocultura, avicultura, caprinocultura e pecuária, especialmente onde se observa uma tendência a reprodução de criação e venda de animais.

Vale ressaltar as origens histórico-culturais da região Nordeste, uma vez que esta é a região de maior alvo do programa AGROAMIGO CRESCER PECUÁRIA. Inicialmente cabe salientar que o modelo econômico do Brasil até 1970 contribuiu, segundo Nunes et al (2014) e Silva et al (2017), para ampliar a pobreza, principalmente das famílias rurais, e as atividades econômicas mais pujantes sempre se concentraram na região Centro-Sul. A concentração, especialmente nas regiões Sul e Sudeste é resultado de um modelo que leva ao aumento das disparidades entre as regiões brasileiras e torna ainda mais marginalizado o meio 
rural, especialmente nas regiões mais pobres, a exemplo das regiões Nordeste e a Norte. (HIRSCHMAN, 1977).

As transformações sociais ocorridas ao longo do tempo, baseado no processo de industrialização formou uma sociedade heterogênea e quase metade da população pobre do Brasil ainda reside na região Nordeste e no meio rural. Entre os fatores que contribuem para tornar vulnerável a população rural no Nordeste, vale destacar os períodos de seca e uma economia rural precária baseada em produtos primários, dando destaque para a pecuária extensiva de baixo potencial genético e pouca produtividade. Atividades não-agrícolas, especialmente com o surgimento de agroindústrias familiares de pequeno porte, têm se mostrado promissoras a partir dos anos 1990 e 2000, como alternativas para a diversificação da economia rural da região Nordeste do Brasil. (MARIANO; NEDER, 2004 apud SILVA, 2009)

Observa-se a partir da Figura 1 as áreas de concentração onde o Programa Agroamigo atua, contando quase em sua totalidade pela atividade pecuarista, de forma análoga é onde se tem um maior número de inadimplentes. Sabe-se dos benefícios trazidos pelo programa para o agricultor familiar e suas organizações coletivas. No entanto, Aquino e Bastos (2015) sinalizam deficiências através de um olhar analítico do programa, no que diz respeito a sua área de atuação limitada.

Figura 1 - Distribuição do Programa Agroamigo por tipo de financiamento

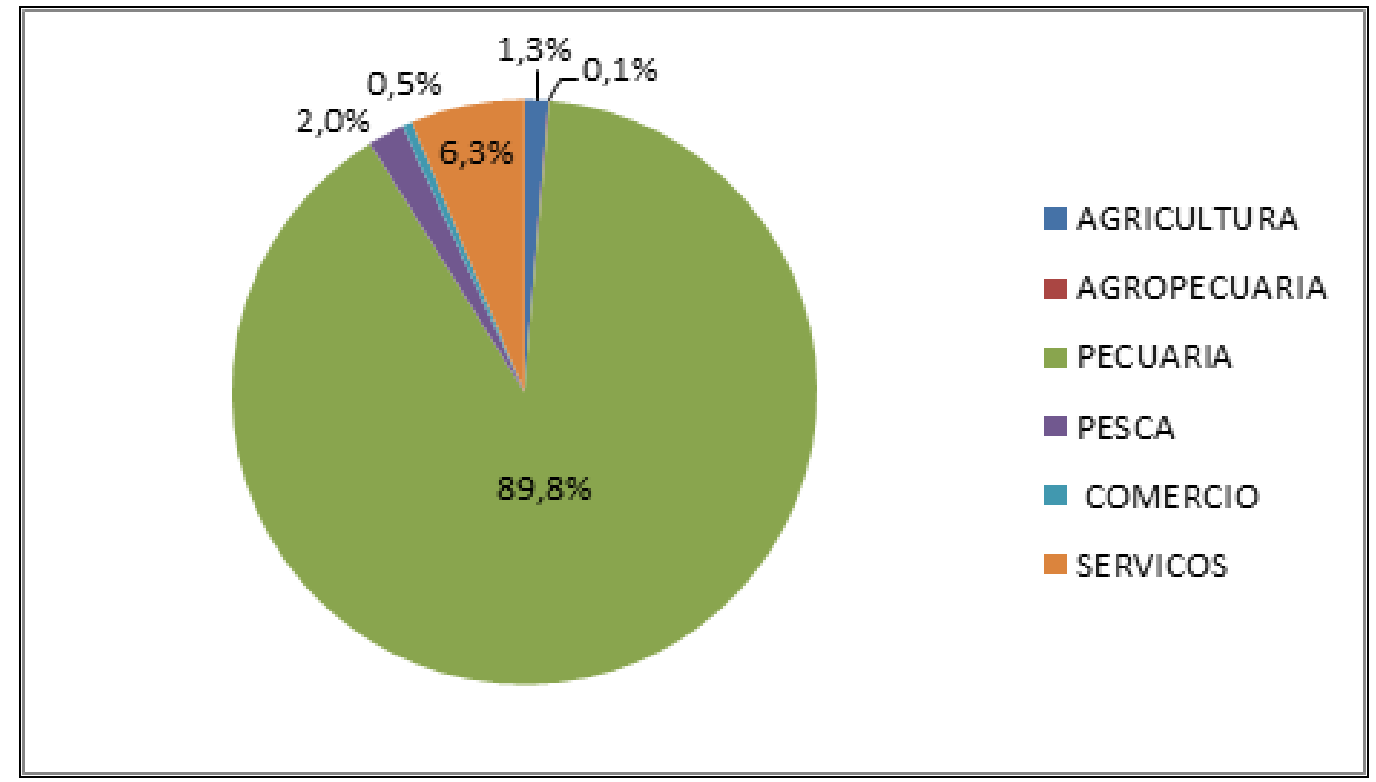

Fonte: Elaboração dos autores, com dados obtidos na base de dados do Agroamigo do BNB.

O Agroamigo trabalha atualmente com duas linhas internas: O Agroamigo Mais e o Agroamigo Crescer, foco deste trabalho, que é voltado para a categoria $B$ do Pronaf, também chamado de Pronaf B. Existe uma necessidade de aperfeiçoar este 
programa de microcrédito, no sentido de dinamizar a economia no meio rural. Após uma análise crítica, um aprendizado que se pode tirar é que o Programa precisa ser ampliado visando atingir as camadas pobres da população rural. Sabe-se que os mecanismos de crédito do livre mercado acabam prejudicando essa camada da população, que dificilmente conseguiria ter acesso aos serviços bancários convencionais, e assim políticas nesse sentido são necessárias. Apesar de o programa Agroamigo ter crescido consideravelmente e o número de agentes intermediadores também, ainda é um número pequeno considerando a demanda. Outra lição é que a monopolização dos investimentos em pecuária torna o meio rural pouco diversificado, assim o programa deveria propor ações que visem mudar este quadro, buscando outras atividades produtivas e diversificar as fontes de renda dos agricultores familiares (ABRAMOVAY ET AL, 2013; BNB, 2013; MAGALHÃES; ABROMOVAY, 2006; SCHRÖDER, 2012 apud AQUINO; BASTOS, 2015).

Segundo Aquino e Bastos (2015) a falta de dinamização em outros setores, e mesmo na infraestrutura produtiva, limita e torna vulneráveis os rebanhos nas épocas de estiagem. Segundo dados do Escritório Técnicos de Estudos do Nordeste (ETENE), do BNB (2015), os níveis de investimento na região Nordeste são elevados. Segundo Nunes et al (2014) o Nordeste ainda conta com infraestrutura de produção econômica precária, devido nessa região os níveis de investimento, apesar de poucos recursos, serem bem maiores que os de custeio. Ao se debruçar sobre a literatura das teorias de crescimento econômico, tem-se o Estado como fonte geradora de desenvolvimento. Na teoria de crescimento Keynesiana, difundidas por estudiosos no mundo inteiro, se analisa o investimento como variável endógena e indispensável para o crescimento e o desenvolvimento econômico.

Para Nunes et al (2015), a região Nordeste, especialmente, demanda um nível maior de investimento buscando ainda construir e desenvolver uma infraestrutura produtiva, e o microcrédito rural acessado isoladamente não melhora a condição dos chamados "agricultores periféricos", sendo necessárias ações no sentido de estimular mais organizações coletivas, especialmente cooperativas de agricultores familiares. Para Aquino e Bastos (2015), políticas em setores não rurais, como infraestrutura de comercio e serviços e educação rural são meios que precisam ser reforçados, é necessário que se estimule o meio rural através de processos com iniciativas de agregação de valor e da diversificação de renda.

Conforme Milton Santos (1977), o desenvolvimento distintivo das sociedades, ou seja, a formação sócio econômica e espacial permite alertar para a formação 
especifica de cada sociedade, bem como suas relações econômicas que caracterizam uma sociedade em determinada época. Segundo o autor, os modos de produção se concretizam sobre uma base social histórica já determinada, assim "[...] as formas espaciais seriam uma linguagem dos modos de produção. Daí, na sua determinação geográfica serem eles seletivos, reforçando dessa maneira a especificidade dos lugares". (MILTON SANTOS, 1977, p. 17).

Para Santos (1977), compreender as especificidades dos lugares é observar sua formação histórica para então entender sua condição econômica. Um lugar tem suas características próprias bem como sua necessidade de transformação social. $O$ uso produtivo dessa localidade é dependente da sua condição efetiva. $O$ modo de produção e a formação social dependem entre outras particularidades, da distribuição de infraestrutura. A infraestrutura e a forma como a população está distribuída nesta, influenciam na evolução das formações econômicas e sociais de um lugar. As transformações no espaço são consequências das necessidades sociais, econômicas e políticas, onde "a produção é resultado de uma pré-condição da produção". Sendo assim a condição econômica de um espaço, no caso estudado por este artigo, a Região Nordeste, dependente de investimento, é devido a sua já formação histórica, social e cultural, enraizada (MILTON SANTOS, 1977, p. 43).

Hirschman (1958) destaca a importância do investimento público juntamente com o investimento privado, no sentido de "dotar a frágil iniciativa privada de regiões mais pobres de musculatura suficiente para desencadear atividades produtivas", dado o pouco interesse da iniciativa privada nas ações de investimento. Desta forma, tem-se o Estado como principal agente na produção do desenvolvimento por meio das ações de investimento, visando expandir a produção econômica, diversificando a formação de renda, contendo e encolhendo as desigualdades sociais e econômicas destas localidades.

Segundo Nunes et al (2015), as ações de custeio agem como insumos financeiros que introduzidos na dinâmica produtiva visam manter e gerar riqueza nova nas já incorporadas infraestruturas de produção. Desta forma é autoexplicativo os baixos níveis de custeio da região Nordeste; devido à falta de infraestrutura. Os autores destacam que níveis de custeio são incorporados por localidades que já possuem uma desenvoltura econômica estruturada. De forma contrária, os níveis de investimentos maiores são direcionados para as localidades mais vulneráveis economicamente, são utilizados ainda para um processo de construção de uma estrutura que, quando pronta, venha possibilitar a utilização de ações de custeio. 
Em relação ao direcionamento dos financiamentos, a Figura 2 mostra que os níveis de investimentos predominam e representam aproximadamente $95 \%$ dos recursos do programa Agroamigo, enquanto os níveis de custeio representam apenas $5 \%$, segundo dados do ETENE do $\mathrm{BNB}^{6}$.

Desta forma atingimos pontos críticos que necessitam de mudanças na operacionalização, pois sugere o Agroamigo um instrumento importante de apoio financeiro e do desenvolvimento da agricultura familiar e de suas organizações coletivas. E, para isto, é necessário um ambiente mais adequado entre outros motivos para manter as famílias no meio rural com mais dignidade, principalmente no que diz respeito à mudança da cultura nordestina nas atividades de criação $e$ venda de animais. A diversificação de renda no campo ajuda a diminuir a inadimplência uma vez que os agricultores não ficam vulneráveis há uma única fonte de renda (AQUINO; BASTOS, 2015).

Figura 2 - Distribuição do financiamento por finalidade Investimento e Custeio

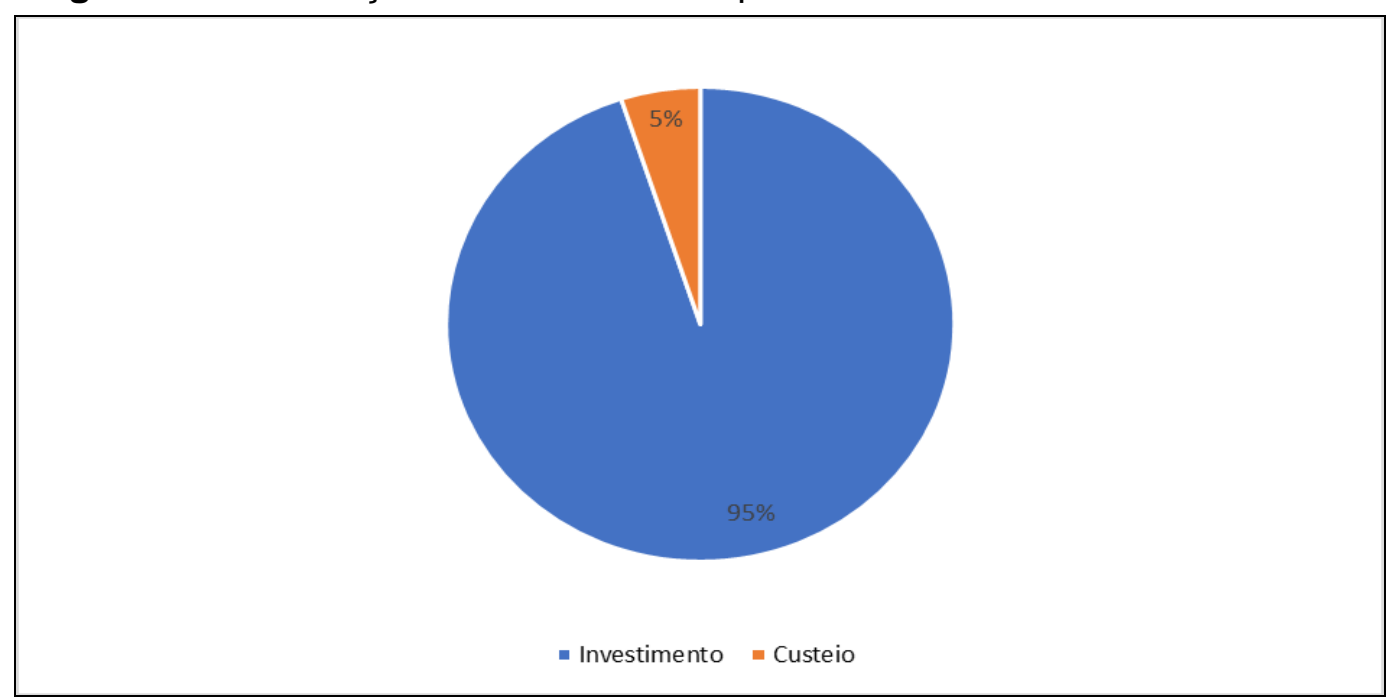

Fonte: Elaboração dos autores, com dados obtidos na base de dados do Agroamigo do BNB.

\section{Aspectos empíricos acerca da inadimplência nos contratos de financiamento da agricultura familiar}

As taxas de inadimplência dos contratos de financiamento da agricultura familiar no Brasil é uma preocupação recorrente das instituições financeiras, e é abordada por diversos estudos que tentam identificar e sistematizar suas causas.

\footnotetext{
${ }^{6}$ A predominância do Investimento Pecuário numa média concentrada em torno de $90 \%$ ao ano é uma especificidade de uma região pouco desenvolvida como a Nordeste, conforme Nunes et al (2014). Essa média se mostra invertida na região Sul do Brasil, onde há maior distribuição nas quatro modalidades, mas numa média predomina em torno de $85 \%$ ao ano do crédito para a agricultura familiar é destinado ao Custeio Agrícola, como constataram Gazolla \& Schneider (2013, p.16).
} 
Segundo Liskauskas (2016) o crédito rural familiar ou empresarial é o setor com menor inadimplência bancária, visto que, em média, somente $0,7 \%$ dos financiamentos não são pagos no prazo devido. Tal fato se deve em grande medida pela condição de que o agricultor familiar dispõe de mais mecanismos de apoio para conseguir pagar suas as dívidas, como, por exemplo, o Programa de Garantia da Atividade Agropecuária (PROAGRO). O endividamento, quando ocorre, se deve principalmente a outras modalidades de crédito que não têm juros subsidiados e apresentam taxas maiores, levando à desorganização financeira do produtor rural.

Abramovay (2008), por sua vez, teoriza que a inadimplência da produção rural familiar se deve a dois fatores distintos. A primeira delas é a falta de tecnologias de concessão de crédito que valorizem o papel dos agentes financeiros, criando, assim, dificuldades na análise formal do risco dos tomadores e gerando travas burocráticas para a concessão. A segunda razão indica que a inadimplência é estimulada pelo sentimento de que os indivíduos não correm risco diante do não pagamento de suas dívidas e à expectativa de que esta será renegociada ou até anistiada, defendida frequentemente por sindicatos e lideranças locais.

Relatório do BNB (2010) vai de encontro ao exposto por Abramovay (2008) e identifica a deficiência na orientação ao agricultor e no acompanhamento dos empreendimentos, como importantes fatores para a elevação da inadimplência. $A$ partir dessa constatação o BNB implementou um novo modelo, por meio de assessores qualificados, além de gerenciamento de clientes em carteira individualizada, vem reduzindo sobremaneira as taxas de inadimplência em relação ao Pronaf B a partir de 2010, conforme pode ser visto na Tabela 2.

Tabela 2 - Comparativo de saldo em atraso e inadimplência (em $\mathrm{R} \$$ mil)

\begin{tabular}{c|c|c}
\hline Modalidade & Saldo em atraso & Inadimplência \\
\hline Pronaf B & $\mathrm{R} \$ 263.866$ & $63,94 \%$ \\
\hline Agroamigo & $\mathrm{R} \$ 33.200$ & $4,68 \%$ \\
\hline
\end{tabular}

Fonte: Banco do Nordeste do Brasil (2010)

É recorrente, também, na literatura que busca avaliar os programas de financiamento da agricultura familiar a construção de modelos estatísticos que visam estabelecer instrumentos objetivos de apoio ao processo de avaliação e risco de crédito para concessão do financiamento. Alves e Camargos (2014), por exemplo, utilizam modelos logísticos para identificar o maior nível de escolaridade, sexo feminino, o indivíduo ser casado, tempo de existência e informalidade do negócio, 
além dos prazos e valores dos contratos de financiamento são possíveis fatores correlacionados com a redução nos níveis de inadimplência no microcrédito.

Silveira Júnior (2012) também utiliza uma aplicação com modelo logístico para identificar fatores que influenciam a inadimplência dos financiamentos realizados pelo BNB no Ceará através do Programa Agroamigo. A partir da aplicação de questionários socioeconômicos, sugerem que as variáveis que influenciam a inadimplência dos financiamentos são o bolsa-família, o estado civil, a escolaridade, o sexo, o prazo do financiamento, a periodicidade das parcelas e a capacidade empresarial dos produtores rurais.

Maia e Pinto (2015) buscaram verificar a eficácia do Programa Agroamigo no desempenho das operações de microcrédito. Em uma análise descritiva dos dados do Pronaf entre 2004 e 2014, os autores identificam que apesar de tanto o país quanto a região Nordeste apresentarem fortes flutuações no crédito ao agricultor familiar, o BNB promoveu uma tendência de crescimento de atendimento aos detentores de Declarações de Aptidão ao Pronaf B (DAP B), com substancial melhoria na sua carteira de crédito e que esses efeitos são consequências da metodologia de concessão de crédito do Programa Agroamigo. Identificam, também, que uma das principais variáveis explicativa para a inadimplência foi a oferta de água, resultado que se mostrou compatível com o perfil dos clientes, majoritariamente pertencentes a áreas semiáridas do Nordeste brasileiro. Outro fator fundamental para o não pagamento regular dos contratos foi a periodicidade das parcelas dos financiamentos, indicando que a probabilidade de inadimplência se eleva quando os pagamentos devem ser realizados com mais frequência.

Barros et al (2015) aplicou um modelo logístico ordenado onde os produtores de frutas do Polo Petrolina-Juazeiro poderiam "escolher" entre ser inadimplente com o setor público ou privado, além de alternativas de adimplência e renegociação das dívidas. Os resultados sugeriram que o descompromisso com as dívidas por parte dos produtores do Polo varia de acordo com o tipo de instituição e que há cinco vezes mais chances de se tornarem inadimplentes com o setor público do que com o setor privado. Além disso, existem divergências quanto aos fatores que explicam a inadimplência entre o setor público e o setor privado. A inadimplência no setor público é relacionada a e a área de plantio, a condição de colono e o número de lotes em que o produtor atua. Já para o setor privado, os fatores significativos foram a condição de ter filhos dependentes, participar de associações e não vender suas frutas por meio de contratos regulares. 
Dumer et al (2017) realizaram uma pesquisa de campo com a aplicação de questionários com agricultores tomadores de crédito para descrever o perfil daqueles que se toraram inadimplentes em seus contratos de financiamento. Os resultados apontaram que o principal fator que leva a inadimplência dos produtores relaciona-se com a falta de planejamento, tanto da produção quanto financeiro, demonstrando a importância de conhecimento mínimo de gestão.

Dessa forma, é perceptível que a inadimplência é uma preocupação recorrente dos agentes financeiros que concedem microcrédito à produção familiar rural. No contexto da literatura empírica sobre o tema parece haver convergência sobre alguns fatores principais como causas prováveis dos não pagamentos. Tais fatores são ligados a falta de conhecimento sobre planejamento por parte dos produtores, bem como a características contratuais, tais como prazos e valores dos contratos de financiamento. Alguns fatores individuais como sexo e idade, além da relação com cooperativas e sindicatos rurais também aparecem com frequência como fatores que influenciam a falta de adimplência dos contratos.

\section{Estratégia Empírica}

De acordo com o IBGE (2018), o Nordeste se apresenta a terceira maior economia entre as cinco regiões do Brasil, considerando o Produto Interno Bruto (PIB). Os dados mostram que a região Nordeste no ano de 2011 tinha uma participação de $13,4 \%$ do PIB brasileiro, enquanto a região Sul tinha $16,2 \%$ e a região Centro-Oeste com uma participação de 9,6\% do PIB. No entanto, a região Nordeste ainda se apresenta com o mais baixo PIB per capita, mesmo a distribuição de renda tendo melhorado significativamente nos anos 2000. Segundo dados da Pesquisa Nacional por Amostra de Domicílios (PNAD, 2019), a renda média do Nordeste teve aumento real de 28,8\% entre os anos de 2004 e 2009, passando de $\mathrm{R} \$ 570$ para $\mathrm{R} \$ 734$ (ainda muito baixo), sendo a região brasileira a apresentar o maior incremento no salário médio do trabalhador no período citado.

O cenário socioeconômico da região Nordeste ainda se apresenta frágil, o que torna necessária a ação de políticas de inclusão capazes de ampliar oportunidades e dinamizar a economia, especialmente do meio rural. Nesse contexto, o Agroamigo se apresenta como mecanismo de inclusão financeira no âmbito da agricultura familiar. Na região, o total de clientes ativos do Programa Agroamigo até o ano de 2017 é de 1.214.344 (Um milhão duzentos e quatorze mil, trezentos e quarenta e 
quatro), na área da Superintendência de Desenvolvimento do Nordeste (SUDENE), o que inclui o norte de Minas Gerais e do Espírito Santo, conforme Figura 3.

Junto a este público foram analisados os dados referentes a 26.966 contratos, portanto, a amostra corresponde a 2,22\% dos beneficiários do programa, obtidos diretamente da base de dados do Programa disponibilizada pelo BNB. A partir do conjunto de dados obtidos, foram definidas quatro variáveis, a fim de modelar os determinantes da inadimplência do programa em estudo.

Figura 3 - Áreas de atuação do BNB e da SUDENE na Região Nordeste

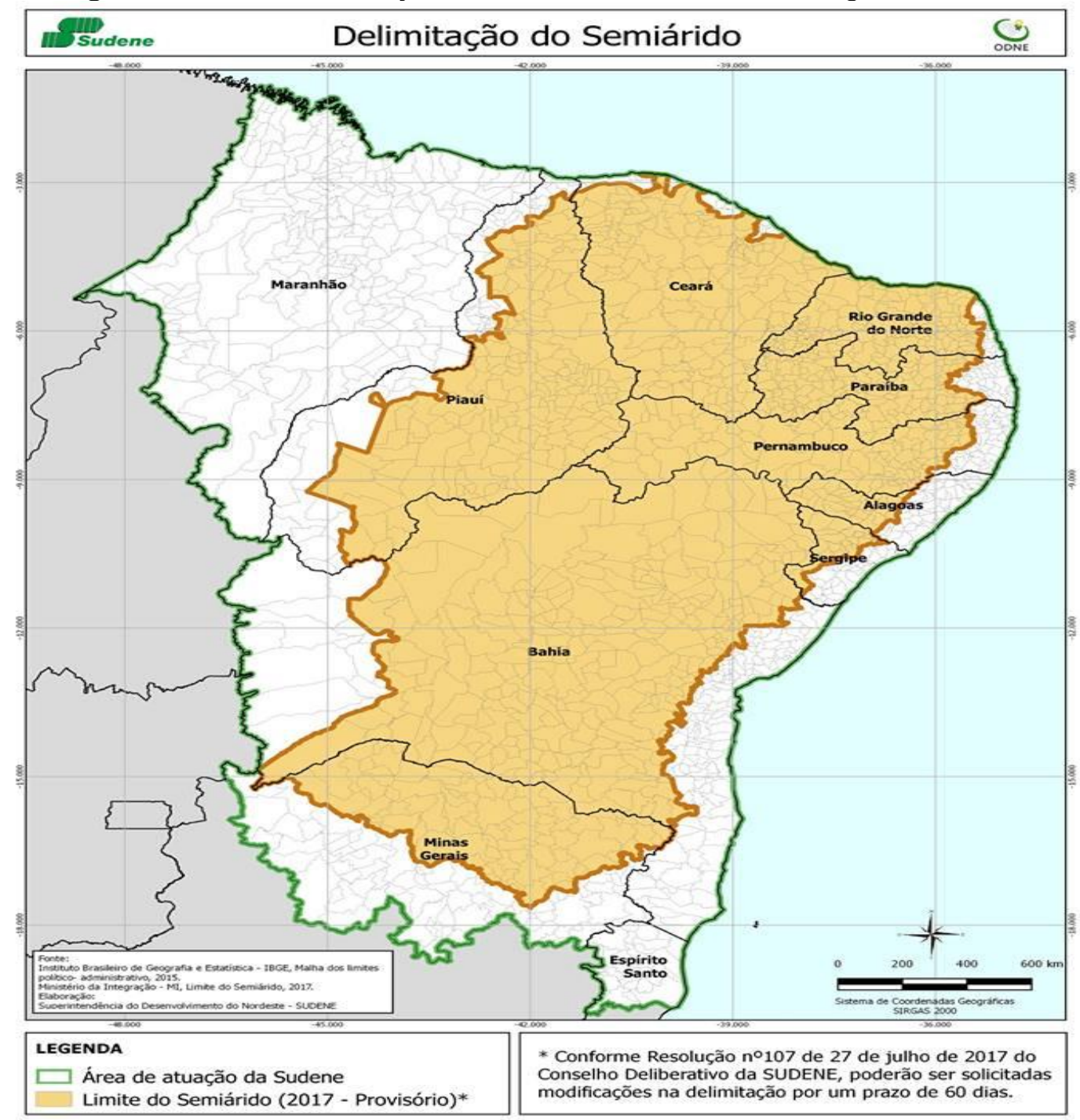

Fonte: Lima, Monte e Militão, 2012.

A Tabela 3 apresenta essas variáveis e suas respectivas estatísticas descritivas. 
Tabela 3 - Definição, descrição e estatísticas descritivas das variáveis selecionadas

\begin{tabular}{|c|l|c|c|c|c|c|}
\hline Variável & \multicolumn{1}{|c|}{ Descrição } & Obs & Média & $\begin{array}{l}\text { Desvio } \\
\text { Padrão }\end{array}$ & Mín & Máx \\
\hline inad & $\begin{array}{l}\text { ldentifica os contratos com saldo } \\
\text { em atraso. Assume valor 1 para } \\
\text { contrato inadimplente e 0, caso } \\
\text { contrário. }\end{array}$ & 23.889 & 0,0159 & 0,1249 & 0 & 1 \\
\hline valor_cont & $\begin{array}{l}\text { Valor da operação de } \\
\text { financiamento, em Reais (R\$). }\end{array}$ & 23.889 & $2.204,42$ & $1.259,21$ & 500 & 15.000 \\
\hline prazo_op & $\begin{array}{l}\text { Prazo da operação de } \\
\text { financiamento, em meses. }\end{array}$ & 23.889 & 29,51 & 20,57 & 4 & 144 \\
\hline finalid & $\begin{array}{l}\text { Finalidade do contrato de } \\
\text { financiamento. Assume valor 1 } \\
\text { para contrato de investimento e 0, } \\
\text { no caso de custeio. }\end{array}$ & 23.889 & 0,9377 & 0,2418 & 0 & 1 \\
\hline sexo & $\begin{array}{l}\text { Sexo do titular do contrato. } \\
\text { Assume valor 1 para homens e 0, } \\
\text { caso contrário. }\end{array}$ & 23.889 & 0,5479 & 0,4977 & 0 & 1 \\
\hline
\end{tabular}

Fonte: Elaboração dos autores, com dados obtidos na base de dados do Agroamigo do BNB.

Para delimitar a amostra, foi estabelecido o prazo mínimo de 4 meses para a duração do contrato, assim como estabelecido pelas diretrizes do programa. O prazo máximo dos contratos estudados é 144 meses, enquanto que o prazo médio de financiamento é de aproximadamente 30 meses. Os valores formalmente contratados variam entre $R \$ 500,00$ e $R \$ 15.000,00$; com média de $R \$ 2.204,42$ por contrato, e o valor mínimo foi estabelecido tendo em conta que a maioria dos contratos, aproximadamente 94\%, são destinados à aplicação em investimentos, sendo em torno de $55 \%$ da amostra composta por homens.

Após a coleta de dados, tabulação e análise preliminar das variáveis levantadas, será posto em execução a modelagem de atribuição de probabilidades aos fatores de percepção levantados. Existem vários modelos empíricos que podem ser utilizados para tal fim, entre eles temos os modelos que trabalham com variáveis categóricas, como o PROBIT, o LOGIT e o Modelo de Probabilidade Linear (MPL), entre outros. Dentre as diversas variações dos modelos de atribuição de probabilidades, este trabalho utilizará o modelo LOGIT de resposta binária.

Segundo Wooldridge (2016), o modelo LOGIT pode ser derivado a partir de um modelo de variável latente subjacente. Seja $y^{*}$ uma variável não observada, ou latente, determinada por:

$$
y^{*}=\beta_{0}+x \beta+e, \quad y=1\left[y^{*}>0\right]
$$

em que a notação $1[\square]$ define um resultado binário. A função $1[\square]$ é chamada de função indicadora, que assume o valor 1 se o evento for verdadeiro e 0 , caso 
contrário. Portanto, $y$ será 1 se $y^{*}>0$ e 0 se $y^{*} \leq 0$. Assumimos que e é independente de $x$ e que e tem a distribuição logística padrão. Assim, e será simetricamente distribuída ao redor de 0 , o que significa que $1-G(-z)=G(z)$ para todos os números $z$ reais. Com base em (1), podemos derivar a probabilidade de resposta de $y$, que será dada por:

$$
P(y=1 \mid x)=P\left(y^{*}>0 \mid x\right)=P\left[e>-\left(\beta_{0}+x \beta\right) \mid x\right]=1-G\left[-\left(\beta_{0}+x \beta\right)\right]=G\left(\beta_{0}+x \beta\right)
$$

Ainda de acordo com Wooldridge (2016), as magnitudes de cada $\beta_{j}$ estimado não são, em si mesmas, de grande valia. Para o nosso propósito devemos estimar o efeito de $x_{j}$ sobre a probabilidade de êxito $P(y=1 \mid x)$, contudo, isso é complicado devido à natureza não linear de $G(\square)$. Assim, faremos uso dos efeitos marginais dos coeficientes obtidos em que, se $x_{j}$ for uma variável aproximadamente contínua, seu efeito marginal sobre $p(x)=P(y=1 \mid x)$ será obtido por:

$$
\frac{\partial p(x)}{\partial x_{j}}=g\left(\beta_{0}+x \beta\right) \beta_{j}, \text { onde } g(z) \equiv \frac{d G}{d z}(z)
$$

A equação (3) mostra que os efeitos relativos de duas variáveis explicativas contínuas quaisquer não dependem de $x$ : a razão dos efeitos parciais de $x_{j}$ e $x_{h}$ é $\beta_{j} / \beta_{h}$. Assim, empiricamente, obtemos as probabilidades associadas à inadimplência média estimada, bem como suas variações relacionadas a cada variável selecionada.

\section{Apresentação e Discussão dos Resultados}

Conforme dito anteriormente, o objetivo central deste trabalho é identificar a inadimplência média, em termos percentuais, bem como suas variações considerando o conjunto de variáveis selecionadas como determinantes. A Tabela 4 a seguir apresenta os coeficientes obtidos a partir das simulações realizadas.

Da Tabela 4 percebemos, claramente, que o sexo do tomador do financiamento não é relevante para a probabilidade deste ser, ou não, inadimplente, visto que seu coeficiente não foi estatisticamente significante. Todavia, será mantida na especificação em virtude do fato de que sua inclusão e/ou exclusão não geram efeitos significativos nas estimativas. Por outro lado, as demais variáveis, inclusive a constante, se mostraram significantes. Dos resultados obtidos, podemos sugerir que quanto maior o valor do contrato de financiamento, maior será a chance de inadimplência, assim como o fato da finalidade do contrato ser direcionada a 
investimentos no negócio. Já o aumento do prazo, segundo os resultados, diminui a chance do tomador se tornar inadimplente. Tais resultados se mostram bastante próximos da realidade empírica encontrada nos agentes de financiamento.

Tabela 4 - Resultados das estimações realizadas para o modelo de inadimplência

\begin{tabular}{ccccc}
\hline Variável & Coef & $\begin{array}{c}\text { Erro } \\
\text { Padrão }\end{array}$ & Estat $z$ & p-value \\
\hline const & $-11,93852$ & 0,6068783 & $-19,67$ & 0,000 \\
valor_cont & 0,001385 & 0,0000716 & 19,36 & 0,000 \\
prazo_op & $-0,0871707$ & 0,0072108 & $-12,09$ & 0,000 \\
finalid & 5,975403 & 0,5199139 & 11,49 & 0,000 \\
sexo & $-0,0447095$ & 0,117927 & $-0,38$ & 0,705 \\
\hline \multicolumn{4}{c}{ Observações } & \multicolumn{4}{c}{ Pseudo $R^{2}$} \\
\hline \multicolumn{2}{c}{23.889}
\end{tabular}

Fonte: Elaboração dos autores com base nos resultados das estimações.

Antes de utilizarmos os resultados obtidos para obtenção das probabilidades, é necessário realizar alguns testes no modelo estimado a fim de verificar sua validade para o fim que nos propomos aqui. Uma medida usual da adequação de um modelo LOGIT é sua capacidade de prever com exatidão uma resposta binária, dados os valores dos termos no modelo. Esta capacidade pode ser resumida em uma tabela de classificação que contabiliza o número de vezes que o modelo ajustado classifica a resposta corretamente, para cada um dos dois valores de resposta. A Tabela 5 apresenta esses resultados.

Considerando um valor de corte de 0,5 , da Tabela 5 vemos que a taxa de casos corretamente avaliados é $98,43 \%$ e, portanto, a taxa global de erro gira em torno de apenas $1,57 \%$; com $99,83 \%$ do grupo dos não inadimplentes corretamente classificados (sensibilidade) e $11,87 \%$ do grupo inadimplente corretamente classificado (especificidade).

Os resultados na Tabela 5 nos levam a sugerir um modelo com alto grau de ajustamento para obtermos as probabilidades de inadimplência.

Tabela 5 - Tabela de classificação do modelo de inadimplência ajustado

\begin{tabular}{cccc}
\hline Classificação & Inad predita $=\mathbf{1}$ & Inad predita $=\mathbf{0}$ & Totais \\
\hline Inad observada $=1$ & 45 & 41 & 86 \\
Inad observada $=1$ & 334 & 23.469 & 19,36 \\
\hline
\end{tabular}

(Continua na próxima página)

Tabela 5 - Continuação 


\begin{tabular}{cccc}
\hline Classificação & Inad predita $=\mathbf{1}$ & Inad predita $=\mathbf{0}$ & Totais \\
\hline Totais & 379 & 23.510 & 23.889 \\
\hline Sensibilidade do modelo estimado & & $11,87 \%$ \\
\hline Especificidade do modelo estimado & & $99,83 \%$ \\
\hline Casos corretamente classificados & & $98, .43 \%$ \\
\hline
\end{tabular}

Fonte: Elaboração própria com base nos resultados das estimações.

Contudo, conforme mostrado por Hosmer e Lemeshow (2000), a classificação é sensível aos tamanhos relativos de cada grupo de componentes e sempre favorece a classificação no grupo maior, ou seja, as tabelas de classificação são muito dependentes da distribuição das observações na tabela de classificação e, assim, podem ser muito enganadoras. Um meio melhor de avaliar a habilidade do modelo LOGIT em classificar as observações com exatidão é uma curva Característica de Operação do Receptor (ROC, da sigla em inglês). Uma curva ROC é construída gerando-se diversas tabelas de classificação, para valores de corte que variam de 0 a 1 e calculando-se a sensibilidade e a especificidade de cada valor. $A$ sensibilidade é traçada contra [1 - especificidade] para construir uma curva ROC. $\mathrm{Na}$ Figura 4 vemos como se comporta a curva ROC para o modelo de inadimplência estimado.

Figura 4 - Curva ROC para o modelo de inadimplência ajustado

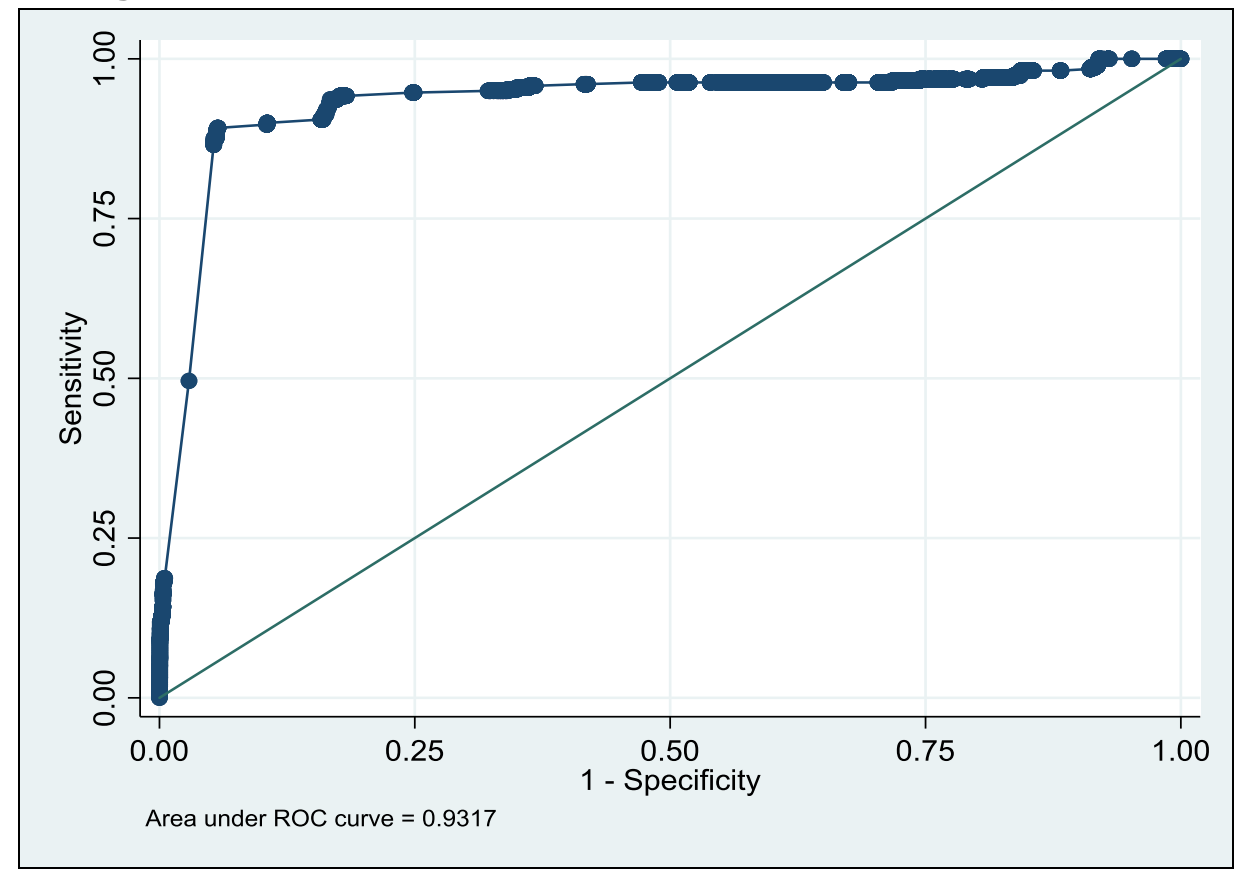

Fonte: Elaboração própria com base nos resultados das estimações.

A área sob a curva ROC (AUC) é uma medida de discriminação. Um modelo com uma área elevada sob a curva ROC sugere que o modelo é capaz de predizer com precisão o valor de uma resposta da observação. Desta forma, como na Figura 
2 e utilizando as regras de análise estabelecidas por Hosmer e Lemeshow (2000), como a área sob a curva ROC para este modelo é $A U C=0,9317$; pode-se sugerir que o modelo fornece uma discriminação excelente para o propósito deste trabalho.

Portanto, após a verificação de que o modelo de inadimplência proposto é adequado para a obtenção das probabilidades relacionadas, estimamos os efeitos marginais conforme equação (03), reportando os resultados na Tabela 6.

Tabela 6 - Efeitos marginais para o modelo de inadimplência estimado

\begin{tabular}{ccccc}
\hline Variável & $\boldsymbol{d} \boldsymbol{y} / \boldsymbol{d} \boldsymbol{x}$ & $\begin{array}{c}\text { Erro } \\
\text { Padrão }\end{array}$ & Estat $\boldsymbol{z}$ & $\boldsymbol{p}$-value \\
\hline valor_cont & 0,00000385 & 0,00000 & 9,57 & 0,000 \\
prazo_op & $-0,0002424$ & 0,00002 & $-10,69$ & 0,000 \\
finalid & 0,0040316 & 0,00052 & 7,81 & 0,000 \\
sexo & $-0,0001246$ & 0,00033 & $-0,38$ & 0,706 \\
\hline$P$ (inad) média estimada & \multicolumn{4}{c}{0,00278854}
\end{tabular}

Fonte: Elaboração própria com base nos resultados das estimações.

Da Tabela 6 vemos que a probabilidade média de um tomador do financiamento ser inadimplente é de $0,2789 \%$. Se considerarmos o valor do contrato, percebemos que, para cada $R \$ 100$ adicionais no valor financiado, a probabilidade de inadimplência aumentará em 0,000385 pontos percentuais. Já em relação ao prazo do contrato, percebemos que para cada mês adicional ao contrato, reduzirá o risco de inadimplência em 0,02424 pontos percentuais. Por sua vez, o fato do contrato ser voltado à investimento na produção aumentará a chance do tomador ser inadimplente em 0,40316 pontos percentuais.

Os resultados obtidos para o modelo de inadimplência estimado apontam para o sentido correto das relações empíricas percebidas. Temos que o aumento do valor do contrato aumenta a chance do tomador se tornar inadimplente e que o aumento do prazo reduzirá essa possibilidade. Enquanto que a finalidade direcionada a investimentos, essa a maior proporção dos contratos, aumentara o risco da inadimplência. Como verificado, essas relações encontram seus paralelos empíricos, apesar do fato de suas variações provocarem baixa variabilidade nas probabilidades médias dos indivíduos.

\section{Considerações Finais}

O Agroamigo é um programa de microfinanças rural que oferece serviços financeiros visando melhorar o perfil social e econômico do agricultor familiar e de suas organizações coletivas, enquadrados em faixas específicas do PRONAF, 
especialmente o Pronaf B. Nesse sentido, este trabalho propôs-se a identificar os determinantes da inadimplência dos tomadores de financiamento a partir de questionários aplicados, especificamente, da linha Agroamigo Crescer Pecuária, atribuindo probabilidades a cada fator relacionado.

Os resultados sugeriram que as relações empíricas da possibilidade de inadimplência com as variáveis relacionadas ao valor e prazo dos contratos, bem como à sua finalidade, condizem com aquelas esperadas e já consolidadas pela literatura, apesar de ser observada baixa variabilidade nas probabilidades médias a partir do modelo ajustado. Outros resultados interessantes são a identificação de baixa inadimplência do programa Agroamigo por parte dos agricultores familiares tomadores, em torno de apenas 3,2\%, além do fato de que o gênero do tomador do financiamento por meio do Agroamigo não ser fator determinante da inadimplência nos contratos formalizados.

Pode-se observar entre outros fatores, a formação social econômica e espacial da região Nordeste como determinante para uma cultura do nordeste brasileiro nas atividades de criação e venda de animais. Outra característica que se destaca na atitude de muitos produtores rurais do Nordeste é a perspectiva do não pagamento de suas dívidas, especialmente as contraídas em bancos públicos, pois e alimentada uma expectativa equivocada de que a dívida pode ser revista, prorrogada, ou até mesmo perdoada, orientada muitas vezes por sindicatos e representantes locais. Essa perspectiva muitas vezes acarreta na inadimplência e, consequentemente, na não possibilidade de diversificação das atividades econômicas, a não ampliação da renda dos agricultores familiares e no enfraquecimento das organizações coletivas, deixando-os vulneráveis a externalidades.

Estas externalidades afetam a renda dos agricultores familiares que além de não usarem o microcrédito para a finalidade correta, acabam desviando a finalidade para o consumo com vistas ao sustento das famílias. Foi verificado que estes agricultores também produzem para autoconsumo, o que torna explicito que 0 microcrédito isolado não é suficiente para dinamizar a agricultura familiar e disparar processos em dinâmicas de desenvolvimento rural. Politicas agregadas a ele, visando à diversificação das atividades no meio rural, como comercio e serviços e a educação rural, são necessárias para um ambiente econômico mais favorável. Foi constatado também que a pequena e deficiente infraestrutura de produção econômica, especialmente da região Nordeste, leva a um nível de investimento maior em relação aos níveis de custeio, o que faz reproduzir um círculo vicioso. 
Apesar de este trabalho ter chegado a resultados interessantes, encontramos dificuldades quanto à disponibilidade de variáveis que poderiam ser incluídas no modelo. Uma agenda de pesquisa futura poderia, assim, abrir o leque de variáveis relacionadas aos contratos bancários, de forma a possibilitar uma maior identificação de fatores relacionados à chance de inadimplência, bem como, a fatores específicos dos tomadores de financiamento, no intuito de identificar se as características pessoais dos indivíduos têm alguma influência para essa condição.

\section{REFERÊNCIAS}

ABRAMOVAY, R. Alcance e limites das finanças de proximidade no combate à inadimplência: O caso do Agroamigo. São Paulo: FIPE, 2008. (Texto para Discussão, n. 10).

ABRAMOVAY, R. et al. Cinco anos de Agroamigo: Retrato do público e efeito do programa. Fortaleza: Banco do Nordeste, 2013.

ALVES, C. M.; CAMARGOS, M. A. Fatores condicionantes da inadimplência em operações de microcrédito. Revista Base, v. 11, n. 1, p. 59-74, 2014.

AQUINO, J. R.; BASTOS, F. Dez anos do Programa Agroamigo na Região Nordeste: evolução, resultados e limites para o fortalecimento da agricultura familiar. Revista Econômica do Nordeste, v. 46, p. 53-69, jul. 2015.

BARROS, E. S. et al. Endividamento agrícola: Quão comprometidos são os produtores do Polo Petrolina-Juazeiro frente a suas dívidas?. Economia Aplicada, v. 19, n. 1, p. 171-200, 2015.

BANCO INTERAMERICANO DE DESENVOLVIMENTNO. Regulamentações das microfinanças. Rio de Janeiro, 2002. Disponível em: <http://www.iadb.org.>. Acesso em: 14 nov. 2019.

BANCO DO NORDESTE DO BRASIL. Experiência: Agroamigo. Relatório. Fortaleza, 2010. Disponível em: https://repositorio.enap.gov.br/bitstream/1/272/1/102\%20-

\%20AGROAMIGO.pdf. Acesso em: 6 jul. 2020.

BANCO DO NORDESTE DO BRASIL. Programas de microfinanças do Banco do Nordeste. Relatório. Fortaleza, 2017. Disponível em: https://www.bnb.gov.br/documents. Acesso em: 14 mar. 2019.

CASTILLO, A. D. M. El microcrédito como instrumento para el alivio de la pobreza: ventajes e limitaciones. Caderno de Desenvolvimento Rural, v. 5, n. 61, p. 93-110, jul./dez. 2008.

DUMER, M. C. R. et al. Inadimplência do Pronaf: Um estudo no município de Afonso Cláudio-ES. Revista de Agronegócio, v. 6, n. 2, p. 36-48, jul./dez. 2017.

FAMÁ, R.; SECURATO, R. Um procedimento para a decisão de crédito pelas bancas. Revista de Administração Contemporânea, v.1, n.1, p. 12-16, 1997. 
IBMEC, 2006, 105 p. Dissertação (Mestrado Profissional em Economia) - Programa de PósGraduação em Administração e Economia, Faculdade de Economia e Finanças IBMEC, Rio de Janeiro, 2006.

GAZOLLA, M.; Schneider, S. Qual? Fortalecimento? da Agricultura Familiar? Uma análise do Pronaf crédito de custeio e investimento no Rio Grande do Sul. REVISTA DE ECONOMIA E SOCIOLOGIA RURAL (IMPRESSO), v. 51, p. 45-68, 2013.

GULLI, H. Microfinance and proverty: questioning the conventional wisdom. Washington, DC: International American Development Bank, 1998, 124 p.

GURGEL, I. A.; NUNES, E. M. A Dinâmica socioeconômica da pecuária do Rio Grande do Norte: Análise da cadeia produtiva do leite do território Sertão do Apodi. Revista

Econômica do Nordeste, v. 50, p. 59-76, 2019.

HOSMER, D. W.; LEMESHOW, S. Applied Logistic Regression. 2 ed. New Jersey: John Wiley \& Sons, 2000.

IBGE. Produto Interno Bruto dos municípios: 2002-2016. Rio de Janeiro: IBGE, 2018. Disponível em:

https://sidra.ibge.gov.br/pesquisa/pib-munic/tabelas. Acesso em: 10 fev. 2019.

IBGE. Pesquisa Nacional porAmostra de Domicílios Contínua - PNAD Contínua. Rio de Janeiro: IBGE,

2019. Disponível em: https://www.ibge.gov.br/estatisticas/sociais/trabalho/9173-pesquisanacional-poramostra-

de-domicilios-continua-trimestral.html?=\&t=resultados. Acesso em: 10 set. 2019.

LIMA, L. D.; MONTE, K. A.; MILITÃO, V. B. Nordeste em Mapas - Fortaleza: Banco do Nordeste, 2012.

LISKAUSKAS, S. Pronaf completa 20 anos com baixa inadimplência. Valor.globo.com, Rio de Janeiro, 28 nov. 2016, 05:00. Disponível em:

https://valor.globo.com/agronegocios/noticia/2016/11/28/pronaf-completa-20-anos-combaixa-inadimplencia.ghtml. Acesso em: 7 jul. 2020.

MAIA, G. B. S; PINTO, A. R. Agroamigo: Uma análise de sua importância no desempenho do Pronaf B. Revista Econômica do Nordeste, v. 46, p. 10-21, jul. 2015.

MACIEL, H. M. ET AL. O impacto do Programa de Microcrédito Rural (Agroamigo) na melhoria das condições das famílias beneficiadas no Estado do Ceará: Um estudo de caso.

Revista Econômica do Nordeste, v. 40, n. 3, p. 559-586, jul./set. 2009.

MONZONI NETO, M. P. Impacto em renda do microcrédito: Uma investigação empírica sobre geração de renda do Crédito Popular Solidário (São Paulo Confia), no município de São Paulo. São Paulo: FGV, 2006, 194 p. Tese (Doutorado em Administração Pública e Governo) - Escola de Administração de Empresas de São Paulo, Fundação Getúlio Vargas, São Paulo, 2006.

NERI, M.; MEDRADO, A. L. Experimentando microcrédito: Uma análise do impacto do Crediamigo no acesso a crédito. Revista Econômica do Nordeste, v. 41, n. 1, p 133-154, jan./mar. 2010.

NUNES, Emanoel Márcio; SILVA, P. S. G.; SILVA, M. R. F.; SÁ, V. C. (2020). O Índice de Condições de Vida (ICV) em Territórios Rurais do Nordeste: evidências para os territórios Açu-Mossoró e Sertão do Apodi, no Rio Grande do Norte. Revista de Economia e 
Sociologia Rural [IMPRESSO], 58(1), e190917. https://doi.org/10.1590/18069479.2020.190917

NUNES, E. M.; SCHNEIDER, S; MATOS-FILHO, J; GODEIRO-NUNES, K. F.; AQUINO, J. R. de. Políticas Agrárias e Agrícolas no Contexto do Desenvolvimento do Nordeste: evolução, desafios e perspectivas. Planejamento e Politicas Publicas (IPEA), v. 43, p. 91 126, 2014.

NUNES, E. M.; ARAUJO, I. J.; FRANÇA, A. R. M.; LIMA, J. S. S. de; MEDEIROS, L. S. Microcrédito, Infraestrutura e Desenvolvimento Rural: o AGROAMIGO Investimento e Custeio na agricultura familiar de territórios do Rio Grande do Norte. Revista Econômica do Nordeste, v. 46, p. 53-69, 2015.

NUNES, E. M.; FRANÇA, A. R. M.; LIMA, J. S. S. de; MEDEIROS, L. S. Novidades (Novelty) na Agricultura Familiar e sua associação com a agroecologia na produção de hortifrutigranjeiros no Território Sertão do Apodi (RN). REDES (SANTA CRUZ DO SUL. ONLINE), v. 23, p. 213-236, 2018.

OLIVEIRA G; CORONATO, M. Como o Brasil entrou, sozinho, na pior crise da história. Epoca.globo.com, Rio de janeiro, 4 abr. 2016, 18:40. Disponível em: https://epoca.globo.com/ideias/noticia/2016/04/como-o-brasil-entrou-sozinho-na-pior-criseda-historia.html. Acesso em: 19 set. 2019.

SANTOS, Milton. Desenvolvimento econômico e urbanização em países subdesenvolvidos: os dois sistemas de fluxos da economia urbana e suas implicações espaciais. In: Boletim Paulista de Geografia, № 53, pp. 35-59, fev. São Paulo: Associação dos Geógrafos Brasileiros/AGB, 1977.

SCHEREINER, M. Informal finance and the design of microfinance. Development in Practice, v. 11, n. 5, p. 637-640, 2001.

SILVA, C. R. F. E.; SILVA, M. R. F.; NUNES, E. M. A operacionalização do Programa de Aquisição de Alimentos (PAA), na modalidade Compra com Doação Simultânea (CDS) no território Açu-Mossoró (RN). Revista EXTENDERE, v. 5, p. 148-165, 2017.

SILVEIRA JÚNIOR, J. A. Fatores que influenciam inadimplência dos financiamentos do Programa Agroamigo do Ceará. Fortaleza: UFC, 2012, 50 p. Dissertação (Mestrado Profissional em Economia do Setor Público) - Programa de Pós-Graduação em Economia, Universidade Federal do Ceará, Fortaleza, 2012.

TRINDADE, L. L; RIGHI, M. B.; VIEIRA, K. M. De Onde Vem o Endividamento Feminino? Construção e validação de um modelo PLS-PM. Revista Eletrônica de Administração, v. 73, n. 3, p. 718-746, 2012.

WOOLDRIDGE, J. M. Introdução à Econometria: Uma Abordagem Moderna. São Paulo: Cengage Learning, 2016.

\section{NOTAS DE AUTOR}

\section{CONTRIBUIÇÃO DE AUTORIA}

Emanoel Márcio Nunes - Concepção, aquisição de financiamento, administração do projeto, coleta de dados, análise de dados, elaboração do manuscrito, participação ativa da discussão dos resultados, revisão e aprovação da versão final do trabalho.

Fábio Lúcio Rodrigues - Concepção, coleta de dados, análise de dados, elaboração do manuscrito, participação ativa da discussão dos resultados, revisão e aprovação da versão final do trabalho. 
Camila Escobar - Coleta de dados, participação ativa da discussão dos resultados e revisão do trabalho.

\section{FINANCIAMENTO}

Este trabalho contou com o auxílio do Conselho Nacional de Desenvolvimento Científico e Tecnológico (CNPq) através do edital Chamada Encomendas COSAE MDA 2013 (APQ), e com 1 (uma) bolsa de Iniciação Científica (IC) do Programa PIBIC/CNPq no período de 1 (um) ano.

\section{CONSENTIMENTO DE USO DE IMAGEM}

Não se aplica.

\section{APROVAÇÃO DE COMITÊ DE ÉTICA EM PESQUISA}

Não se aplica.

\section{CONFLITO DE INTERESSES}

Não se aplica.

\section{LICENÇA DE USO}

Este artigo está licenciado sob a Licença Creative Commons CC-BY. Com essa licença você pode compartilhar, adaptar, criar para qualquer fim, desde que atribua a autoria da obra.

\section{HISTÓRICO}

Recebido em: 23-03-2020

Aprovado em: 23-10-2020 